\title{
Probability of surface fire spread in Brazilian rainforest fuels from outdoor experimental measurements
}

\author{
Guenther Carlos Krieger Filho ${ }^{1}$ Paulo Bufacchi ${ }^{1} \cdot$ José Carlos Santos $^{2}$. \\ Carlos Alberto Gurgel Veras ${ }^{3} \cdot$ Ernesto C. Alvarado $^{4} \cdot$ William Mell $^{5} \cdot$ \\ João Andrade Carvalho Jr. ${ }^{6}$
}

Received: 10 May 2016/Revised: 23 December 2016/Accepted: 30 December 2016/Published online: 21 January 2017

(c) Springer-Verlag Berlin Heidelberg 2017

\begin{abstract}
This paper describes the development of a logistic model to predict the probability of surface fire spread in Brazilian rainforest fuels from outdoor experimental measurements. Surface fires spread over litter composed mostly of dead leaves and twigs. There were 72 individual outdoor experiments in eighteen sites. The fire propagated in $49 \%$ of the experiments. In each experiment, the litter height, litter temperature, unburned litter mass, wet and dry litter mass, soil temperature, wet and dry soil mass, ambient wind velocity, ambient air temperature, ambient air relative humidity and duration of fire spread were measured. Using these data, the rate of fire spread, litter bulk density, litter and soil moisture content, litter load and litter residue fraction were determined. For the sake of analysis, experimental results were classified into two groups: one for which the fire propagated and the other
\end{abstract}

Communicated by Jarmo Holopainen.

Guenther Carlos Krieger Filho

guenther@usp.br

1 Universidade de São Paulo (USP), Av. Prof. Mello de Morais 2231, São Paulo, SP CEP 05508-030, Brazil

2 Instituto Nacional de Pesquisas Espaciais (INPE), Rodovia Presidente Dutra km 40, Cachoeira Paulista, SP CEP 12630-000, Brazil

3 Universidade de Brasília (UnB), Asa Norte, Brasília, DF CEP 70910-900, Brazil

4 School of Environmental and Forest Sciences, University of Washington, Mail Box 352100, Seattle, WA 98195, USA

5 U.S. Forest Service Pacific Northwest Research Station, Pacific Wildland Fire Sciences Lab, Seattle, WA, USA

6 Universidade Estadual Paulista (UNESP), Av. Ariberto Pereira da Cunha 333, Guaratinguetá, SP CEP 12516-410, Brazil one for which the fire self-extinguished. Analyses of a logistic regression model showed that the relevant parameters for fire propagation are litter height and litter moisture content. Concerning the probability of successful fire propagation, the model showed a true positive rate of $71 \%$ and a true negative rate of $84 \%$. The outdoor experiments also served to gather data to improve the understanding of surface fires and to provide input data for future computer simulations.

Keywords Surface fire - Brazilian rainforest .

Flammability $\cdot$ Logistic regression model

\section{List of symbols}

A Area of the frame used to determine litter mass, litter height and soil mass for measurement $\left(\mathrm{m}^{2}\right)$

AT Ambient air temperature $\left({ }^{\circ} \mathrm{C}\right)$

DLM Dry litter mass (g)

DSM Dry soil mass $(\mathrm{g})$

$i \quad$ Auxiliary variable [-]

LBD Litter bulk density $\left(\mathrm{kg} \mathrm{m}^{-3}\right)$

LH Litter height $(\mathrm{cm})$

LL Litter load $\left(\mathrm{kg} \mathrm{m}^{-2}\right)$

LMC Litter moisture content [-]

LRF Litter residue fraction $[-]$

LT Litter temperature $\left({ }^{\circ} \mathrm{C}\right)$

$m \quad$ Vegetation, soil or residue mass $(\mathrm{g})$

$n \quad$ Number of values of a variable [-]

Pr Probability associated with the logistic regression model [-]

RH Ambient air relative humidity [-]

ROS Rate of spread $\left(\mathrm{cm} \mathrm{min}^{-1}\right)$

SMC Soil moisture content [-]

ST Soil temperature $\left({ }^{\circ} \mathrm{C}\right)$

$u \quad$ Standard uncertainty [variable] 
$V \quad$ Volume $\left(\mathrm{m}^{3}\right)$

$\bar{x} \quad$ Mean of a variable list of values [variable]

$x \quad$ Value of a variable [variable]

$\beta \quad$ Coefficients in the logistic equation [-]

$\Delta d \quad$ Distance travelled by the fire, measured between two thermocouples $(\mathrm{cm})$

$\triangle \mathrm{LM}$ Difference between wet and dry litter masses $(\mathrm{g})$

$\Delta \mathrm{SM}$ Difference between wet and dry soil masses (g)

$\Delta t \quad$ Elapsed time for the fire travelled distance (s)

$\theta \quad$ Independent variables in the logistic equation [variable]

$\sigma \quad$ Standard deviation [variable]

$\begin{array}{ll}\begin{array}{l}\text { Subscripts } \\ \mathrm{d}\end{array} & \begin{array}{l}\text { Combined } \\ \text { Dry vegetation or soil (zero moisture } \\ \text { content) } \\ \text { Vegetation litter, composed mostly of } \\ \text { dead leaves and twigs }\end{array} \\ \text { litter } & \begin{array}{l}\text { Indicates that the fire propagated and } \\ \text { reached a perimeter thermocouple }\end{array} \\ \text { propagated } & \begin{array}{l}\text { Vegetation residue from the litter } \\ \text { burning, including leaves and twigs } \\ \text { char and unburned material }\end{array} \\ \text { residue } & \begin{array}{l}\text { Indicates that the fire self-extinguished } \\ \text { before reaching a perimeter } \\ \text { thermocouple }\end{array} \\ \text { self-extinguished } & \text { Soil material } \\ \text { Wet vegetation or soil }\end{array}$

\section{Introduction}

The Amazon is a tropical rainforest stretching over the basin of the Amazon River, a vast natural tropical region of about 6.74 million $\mathrm{km}^{2}$, which spans seven countries: Bolivia, Brazil, Colombia, Ecuador, Guyana, Peru and Venezuela. About $60 \%$ of this biome belongs to Brazil. If this rainforest were a country, it would be the seventh largest in the world (WWF-BRASIL 2015).

Major threats to the sustainability of the Amazon forest continue to be the persistent high rates of deforestation, ecosystem degradation and increasing occurrence of forest fires (Malhi et al. 2008; Cochrane and Laurance 2008; Alencar et al. 2015). Low intensity and slow-moving surface fires are the most common type in moist tropical forests (Cochrane et al. 1999; Carvalho et al. 2010). Nevertheless, surface fire can be devastating for the ecosystem due to the low resilience of tropical forests. Despite the global importance of tropical fires, little is known on the physics that controls its propagation (Bufacchi et al. 2016). To improve our understanding, we need laboratory and field experiments. However, field experiments can be complex, expensive or even prohibitive. Regrettably, in outdoor fire experiments, only a modest number of dependent variables may be controlled. To improve the means and tools for a more comprehensive investigation on fire propagation, computational numerical models are being developed or improved (Morvan and Dupuy 2001, 2004; Mell et al. 2007, 2009). Regardless of their complexity, numerical models require validation against experiments performed under suitably analogous conditions.

Laboratory and field experiments can provide reliable input data for numerical simulations. Examples of such experiments are the ones performed in France by Morandini et al. (2006), Santoni et al. (2006) and Silvani and Morandini (2009) in tall and dense Mediterranean shrubs and those performed in the USA in wild grasses of southern Texas by Clements et al. (2007). These ecosystems and vegetation types, however, largely differ from those found in the Brazilian rainforest.

Research groups from Brazil and elsewhere have conducted field fires experiments in this tropical forest. Carvalho et al. (1995, 2001) and Araújo et al. (1999) determined carbon mass balance, air temperatures and heat transfer rates in the soil. An important observation of Carvalho et al. (1995) was that the temperature within the soil increases very little during and after the burning of vegetation. A maximum increase of $3{ }^{\circ} \mathrm{C}$ in temperature was observed at a soil depth of $3 \mathrm{~cm}$. Carvalho et al. (2002) investigated the process of $\log$ smoldering in tropical fires. Understory fire propagation and tree mortality in areas neighboring an Amazonian deforestation fire were also investigated in Carvalho et al. (2010). Balch et al. (2015) conducted a large-scale experiment in the southeast of Amazon to investigate the drivers of forest flammability and vulnerability. The study confirms the complex interactions that drive fire behavior and effects of repeated burnings in successional pathways in the Amazon forest. Bufacchi et al. (2016) used data from two fire site observations in the Brazilian rainforest, in the States of Acre and Mato Grosso, as input to determine the rate of fire spread by numerical simulations.

In recent years, there have been a great number of fire behavior studies, each with its own statistical model to predict if the fire spreads or not. Some studies are related to the fire ignition itself, such as Dimitrakopoulos and Papaioannou (2001). Others study the probability of fire spreading in different vegetation types and configurations such as porous beds of woody fuels (Wilson 1985), live chaparral shrub fuels (Weise et al. 2005; Zhou et al. 2005), maritime pine stands (Fernandes et al. 2008) and mixed wood boreal forest surface fuels (Dickinson et al. 2013). The resulting statistical models fit specific fire environments. These models can adeptly represent data collected from a few types of vegetation under certain fuel and weather conditions, but they fail to represent fire 
propagation in different fuel and weather conditions. To the authors' knowledge, there is not a flammability study regarding the Brazilian rainforest. Therefore, one main goal of this paper is to fit experimental data to a logistic regression model to predict fire propagation.

Surface fires in the Brazilian rainforest ecosystem are characterized by the burning of dead and undergrowth vegetation, such as herbs, leaf litter layer and twigs. These fires do not cause significant damage to large trees, but are extremely harmful to young plants and the lower vegetation (Silva 1998). In addition, surface fires are difficult to detect by satellites used for fire monitoring (INPE 2015).

The major goal of the experimental work was to gather field data to improve the understanding of surface fire spread in the Brazilian rainforest, to provide input data to future computer simulations and to fit a logistic model to explain the propagation and self-extinguishment of surface fires.

\section{Materials and method}

The litter burning experiments were conducted in the Brazilian rainforest region in the State of Rondônia (Fig. 1). All the fire experiments were conducted under the forest canopy.

\section{Planning and methodology of the experiments}

Fire rate of spread (ROS) is the result of the coupled processes of heat generated by gas-phase combustion and convective and radiative transfer of heat that promotes the thermal degradation of the unburned vegetation, which, in turn, provides gaseous fuel to sustain the fire.

Numerical models typically require a certain number of thermophysical properties for the fuel bed, which need accurate measurement (Morvan and Dupuy 2001, 2004; Mell et al. 2007, 2009; Bufacchi 2014), namely

(a) Litter height (LH);

(b) Litter bulk density $\left(\mathrm{LBD}=\frac{m_{\text {dry }}}{V_{\text {litter }}}\right)$, estimated from the mass of dry vegetation (obtained by drying the litter samples) and the volume of the litter;

(c) Initial litter temperature (LT), taken before fire ignition;

(d) Litter moisture content $\left(\mathrm{LMC}=\frac{\left(m_{\mathrm{wet}}-m_{\mathrm{dry}}\right)}{m_{\mathrm{dry}}}\right)$, estimated from the wet and dry litter masses;

(e) Litter residue fraction $\left(\mathrm{LRF}=\frac{m_{\text {residue }}}{m_{\text {dry }}}\right)$, where $m_{\text {residue }}$ is the mass of residue after burning the litter.

Other important variables were also measured, such as unburned litter mass, soil temperature (ST), wet soil mass, dry soil mass, ambient wind velocity and time of fire spread, in order to assess their relevancy to the measured ROS. The equations relating these variables are summarized in "Appendix 1."

For the experiments reported here, we chose a site in the State of Rondônia, which is representative of the Amazon biome. An area of $150 \mathrm{~m}$ by $150 \mathrm{~m}$ was selected, and a transect methodology was utilized to locate a group of seven experiment sites. In addition to that, eleven more sites were located inside the $150 \mathrm{~m}$ by $150 \mathrm{~m}$ area, giving a total of eighteen sites. This second group of sites was chosen based on clear areas (absence of trees).

Four experiments were carried out for each experiment site. This way, four measurements, taken in the cardinal directions, north, south, east and west were planned for every variable in each experiment site. A total of seventytwo experiments were carried out.

Figure 2 depicts the transect utilized for the first group of seven experiment sites.

A $10-\mathrm{m}$ variation in the site location, along transects, allowed ensuring a clear area for the experiment. All the experiment sites were $3 \mathrm{~m}$ in diameter and, for safety reasons, foliage, twigs and branches were removed from a 40-cm-wide band around them. This procedure avoided fire propagation out of the circular experiment sites. The center of the experiment site was always accessed from the northwest. While stepping back, attempts were made to return the litter to conditions prior to walking on the site. For ease of reference, the site center and the 1.5-m-radius boundaries along the cardinal directions were identified by wood sticks. Figure 3 shows the experiment site configuration.

A meteorological station was placed in the middle of the $150 \mathrm{~m} \times 150 \mathrm{~m}$ area, in order to measure the ambient air temperature, ambient air relative humidity and ambient wind velocity (speed and direction). The meteorological station was placed $1.5 \mathrm{~m}$ above the ground the day before the first experiment and removed after the experimental campaign. It collected data every $15 \mathrm{~s}$ and recorded the average values every $30 \mathrm{~min}, 24 \mathrm{~h}$ a day. The field experiments were carried out from August 20, 2014, to August 25, 2014, from 11 A.M. to 5 P.M.

Eight type-K thermocouples were installed in each experiment site lining up with the cardinal directions: four in the center, along a 40-cm-diameter circle, and four at the boundaries (1.5 m radius), as shown in Fig. 3. ROS was calculated based on the elapsed time for the fire to propagate outwards the cardinal directions, between the respective pairs of temperature sensors. Elapsed time was estimated from peak temperatures, as a result of the passage of the fire front. Fire ignition was always in the center of the experiment site.

In order to measure the ambient wind speed in the experiment site, four vane anemometers were positioned 


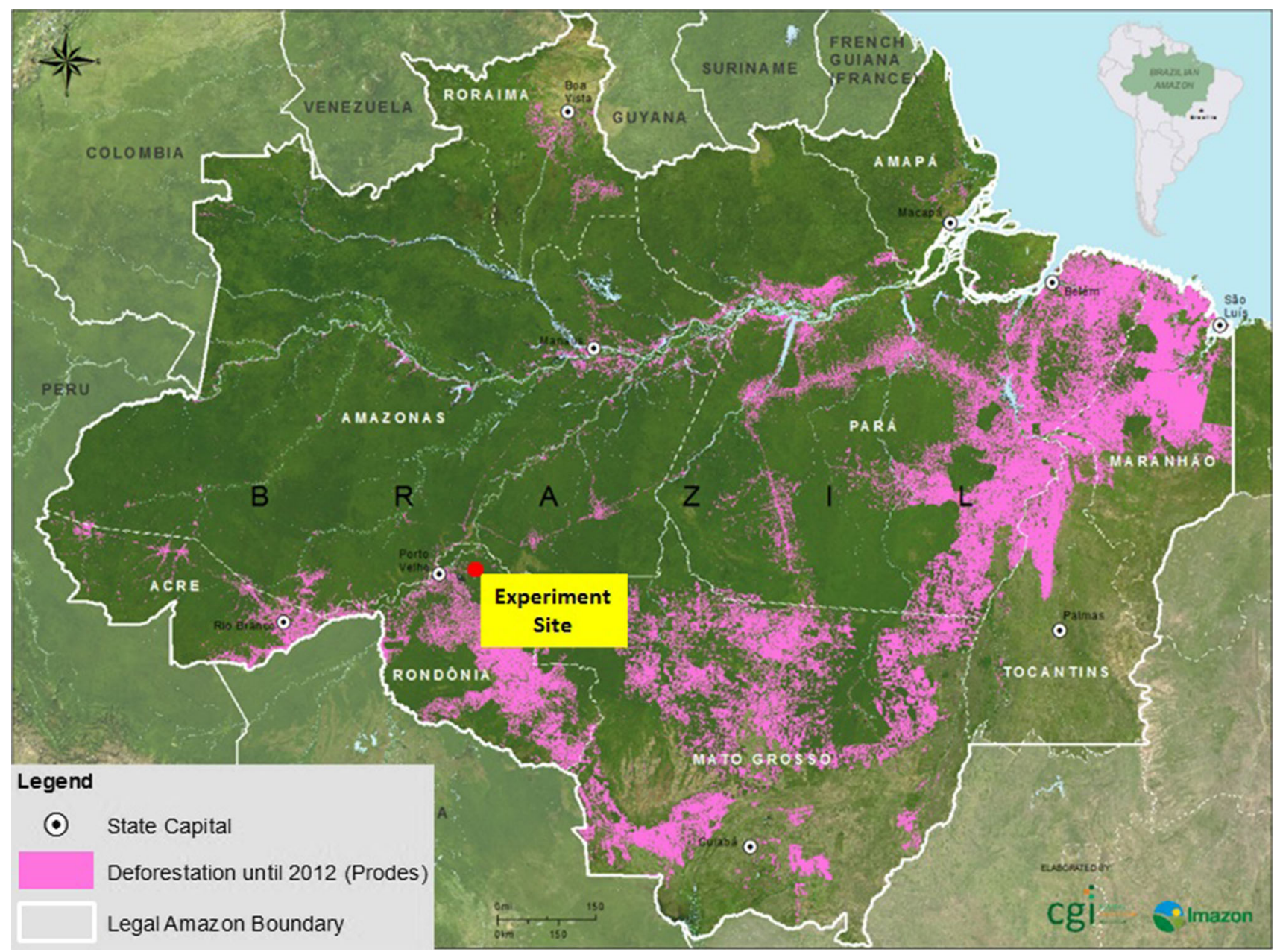

Fig. 1 Location of the litter burning experiments

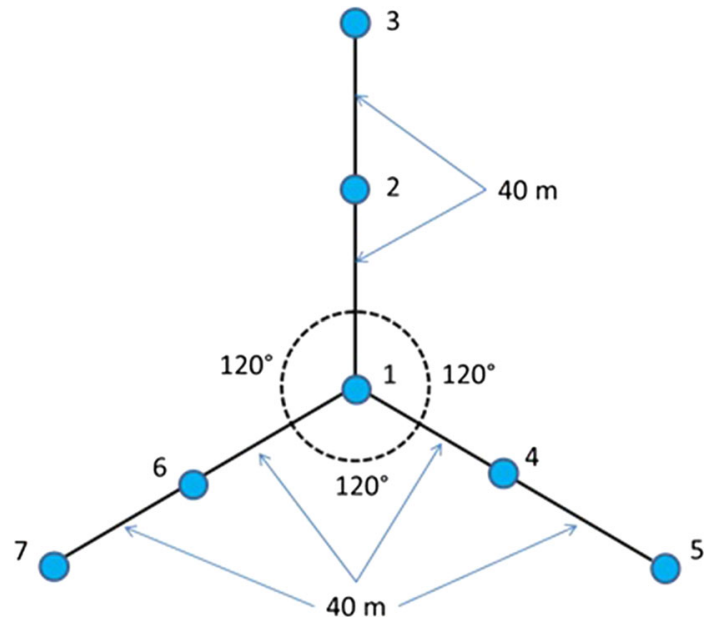

Fig. 2 Transect utilized for site selection

$1.90 \mathrm{~m}$ from the center of the site, along each cardinal direction, at a height of $70 \mathrm{~cm}$. The anemometers height was chosen to avoid the influence of the in-draft air movement caused by the approximately 30-cm-high fire front. The range of measurement of the vane anemometer was from 0.4 to $30 \mathrm{~m} \mathrm{~s}^{-1}$.

In situ measurements of litter, soil and residue mass, litter height, soil and litter temperature were concentrated in four circular areas of $29 \mathrm{~cm}$ in diameter (frame), along the four cardinal directions, as depicted in Fig. 3.

\section{Execution of the experiments}

Seventy-two outdoor experiments were conducted measuring litter height, litter temperature, unburned litter mass, wet and dry litter mass, soil temperature, wet and dry soil mass, ambient wind velocity, ambient air temperature, ambient air relative humidity and time of fire spread. These data allowed calculating the rate of fire spread, litter bulk density, litter and soil moisture contents, litter load and litter residue fraction.

Prior to ignition, ambient wind speed was taken in all cardinal directions in addition to the ambient wind velocity recorded by the meteorological station. After the fire started, the ambient wind speed was taken at time intervals of 


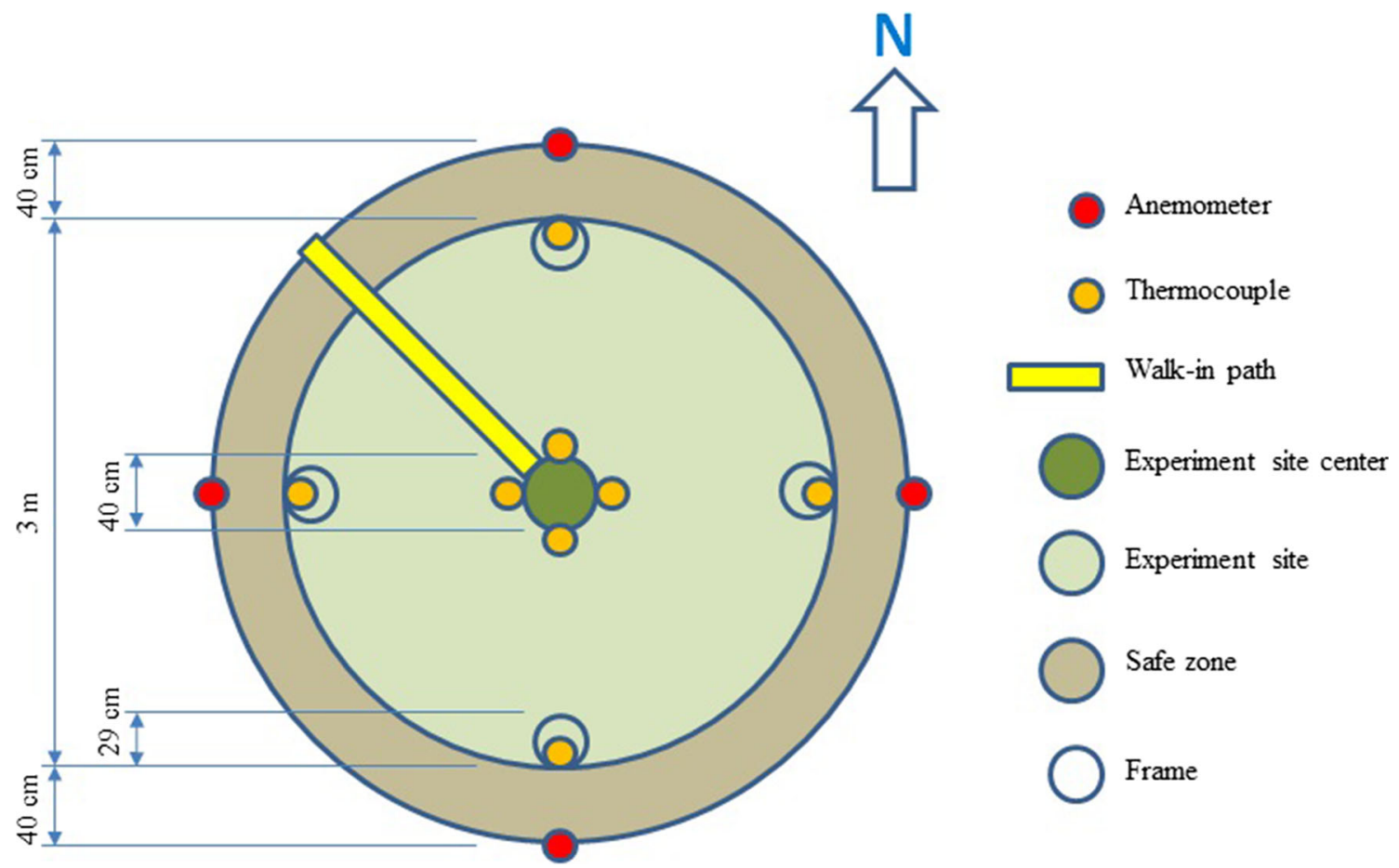

Fig. 3 Experiment site configuration

3 min by the four anemometers. In all site measurements, the ambient wind speed was below the range of the anemometer (i.e., less than $0.4 \mathrm{~m} \mathrm{~s}^{-1}$ ).

Vegetation and soil temperatures were registered using a portable infrared thermometer (RayTek MiniTemp MT6) in all cardinal directions, before fire ignition.

Ignition started at the center of the experiment site by means of a small amount of ethanol poured inside a $10-\mathrm{cm}-$ diameter area and ignited with a match.

Measurements of litter height were made in the four in situ 29-cm-diameter circular frames. Biomass samples of the $29-\mathrm{cm}$ circular frames were weighed and the values recorded as wet litter mass. Afterward, the weighed litter was put into plastic bags, sealed and labeled. The litter bags were sent to INPE (National Institute for Space Research) Combustion Laboratory in Cachoeira Paulista, State of São Paulo, to measure the litter dry mass. Drying was conducted at $75{ }^{\circ} \mathrm{C}$ oven temperature until the weight of the sample stabilized. The same amount of litter, collected just outside the experiment area, replaced the mass extracted for sampling before the burn.

Soil samples from the 29-cm frames were also collected, weighed and the values recorded as wet soil mass. Afterward, the samples were put into plastic bags, sealed and identified. The soil bags were sent to EMBRAPA (Brazilian Agricultural Research Corporation) laboratory in Porto Velho, State of Rondônia. There, the samples were oven dried at $105^{\circ} \mathrm{C}$ for $48 \mathrm{~h}$ and weighed. The values were recorded as dry soil mass. The same amount of soil, collected from the external vicinity of the $29-\mathrm{cm}$ frame, replaced the mass extracted for sampling.

\section{Results and discussion}

ROS was calculated for the cardinal directions in which the fire propagated from the center up to the site boundary. If the fire propagation stopped before the site boundary, the fire was said to have self-extinguished. The fire propagated in $49 \%$ of the seventy-two experiments.

Tables 7 and 8 in "Appendix 2" present the results of the litter, soil and ambient experimental data measured in the field and calculated variables for the propagating and self-extinguished fires, respectively. ROS of the propagating fires is highlighted in Table 7.

Table 1 shows average values, standard deviation, coefficient of variability, and standard uncertainty of measured and calculated variables. The data were split into two sets, the one where the fire propagated and the other one where the fire self-extinguished.

For most of the parameters, the standard deviation for both the measured and calculated variables are high. The coefficient of variation, defined as the ratio between standard deviation and average, is accordingly high. Statistical modeling for the ROS cannot be obtained when the coefficient of variation is greater than 0.2 (Montgomery and Runger 2014). As shown in Table 1, except for ambient air, soil and litter 
Table 1 Statistical parameters of the measured and calculated variables

\begin{tabular}{|c|c|c|c|c|}
\hline & Average & SD & Coefficient of correlation & Standard uncertainty \\
\hline \multicolumn{5}{|l|}{ Fire propagated experiments } \\
\hline \multicolumn{5}{|l|}{ Measured variables } \\
\hline Litter temperature $\left({ }^{\circ} \mathrm{C}\right)$ & 28.7 & 1.3 & 0.05 & 1.5 \\
\hline Litter height $(\mathrm{cm})$ & 3.6 & 1.9 & 0.54 & 0.1 \\
\hline Litter mass $(\mathrm{g})$ & 74.2 & 27.1 & 0.37 & 0.2 \\
\hline Litter dry mass (g) & 59.1 & 21.5 & 0.36 & 0.3 \\
\hline Litter residue mass $(\mathrm{g})$ & 23.5 & 10.2 & 0.44 & 0.2 \\
\hline Soil temperature $\left({ }^{\circ} \mathrm{C}\right)$ & 26.3 & 1.7 & 0.07 & 1.5 \\
\hline Soil mass $(\mathrm{g})$ & 341 & 188 & 0.55 & 2.0 \\
\hline Soil dry mass (g) & 256 & 146 & 0.57 & 2.9 \\
\hline Air temperature $\left({ }^{\circ} \mathrm{C}\right)$ & 31.9 & 2.2 & 0.07 & 0.2 \\
\hline Air relative humidity $(\%)$ & 61.3 & 8.2 & 0.13 & 2.0 \\
\hline \multicolumn{5}{|l|}{ Calculated variables } \\
\hline Litter moisture content $[-]$ & 0.26 & 0.35 & 31.64 & 0.89 \\
\hline Litter bulk density $\left(\mathrm{kg} / \mathrm{m}^{3}\right)$ & 31.64 & 17.57 & 0.56 & 1.56 \\
\hline Litter load $\left(\mathrm{kg} / \mathrm{m}^{2}\right)$ & 0.89 & 0.33 & 0.36 & 0.08 \\
\hline Residue fraction $[-]$ & 0.44 & 0.25 & 0.57 & 0.01 \\
\hline Rate of spread-ROS (cm/min) & 15.1 & 3.9 & 0.26 & 1.2 \\
\hline Soil moisture content $[-]$ & 0.35 & 0.09 & 0.25 & 0.03 \\
\hline \multicolumn{5}{|l|}{ Fire self-extinguished experiments } \\
\hline \multicolumn{5}{|l|}{ Measured variables } \\
\hline Litter temperature $\left({ }^{\circ} \mathrm{C}\right)$ & 29.4 & 1.3 & 0.05 & 1.5 \\
\hline Litter height $(\mathrm{cm})$ & 1.6 & 0.5 & 0.32 & 0.1 \\
\hline Litter mass $(\mathrm{g})$ & 63.4 & 24.0 & 0.38 & 0.2 \\
\hline Litter dry mass $(\mathrm{g})$ & 49.5 & 17.9 & 0.36 & 0.3 \\
\hline Soil temperature $\left({ }^{\circ} \mathrm{C}\right)$ & 27.1 & 1.3 & 0.05 & 1.5 \\
\hline Soil mass $(\mathrm{g})$ & 257 & 96 & 0.37 & 2.0 \\
\hline Soil dry mass (g) & 200 & 76 & 0.38 & 2.9 \\
\hline Air temperature $\left({ }^{\circ} \mathrm{C}\right)$ & 32.2 & 0.8 & 0.02 & 0.2 \\
\hline Air relative humidity $(\%)$ & 61.6 & 4.0 & 0.06 & 2.0 \\
\hline \multicolumn{5}{|l|}{ Calculated variables } \\
\hline Litter moisture content $[-]$ & 0.28 & 0.07 & 0.24 & 0.01 \\
\hline Litter bulk density $\left(\mathrm{kg} / \mathrm{m}^{3}\right)$ & 48.43 & 20.45 & 0.42 & 3.50 \\
\hline Litter load $\left(\mathrm{kg} / \mathrm{m}^{2}\right)$ & 0.75 & 0.27 & 0.36 & 0.00 \\
\hline Soil moisture content $[-]$ & 0.30 & 0.09 & 0.29 & 0.03 \\
\hline
\end{tabular}

temperatures, air relative humidity and litter moisture content, all the other parameters show coefficient of variation greater than 0.2 . Consequently, it is not possible to find a correlation between ROS and the relevant physical parameters. Therefore, we restrict our data analyses to the flammability of the litter. An evaluation of Type B (National Institute of Standards and Technology 2016) standard uncertainty was carried out in order to investigate the results. "Appendix 1" lists the equations used to calculate the appropriate parameters and Type B uncertainty $(u)$ propagation. In order to evaluate Type A uncertainty, one should take a statistically significant number of measurements of each variable while keeping the others constant, which is not feasible in outdoor fire experiments. Therefore, Type B standard uncertainty was assumed as the standard uncertainty (see Table 1). Furthermore, for variables calculated upon measured quantities, the uncertainty should be evaluated taking into account the propagation of the measurement error, resulting in the combined standard uncertainty $\left(u_{\mathrm{c}}\right)$ (see "Appendix 1"). The uncertainty of the difference of the same variable should also be evaluated with the combined standard uncertainty.

Figure 4 shows the mean litter moisture content, average soil moisture content, average litter bulk density, average litter load and average litter height extracted from Table 1 for propagated and self-extinguished fires. 

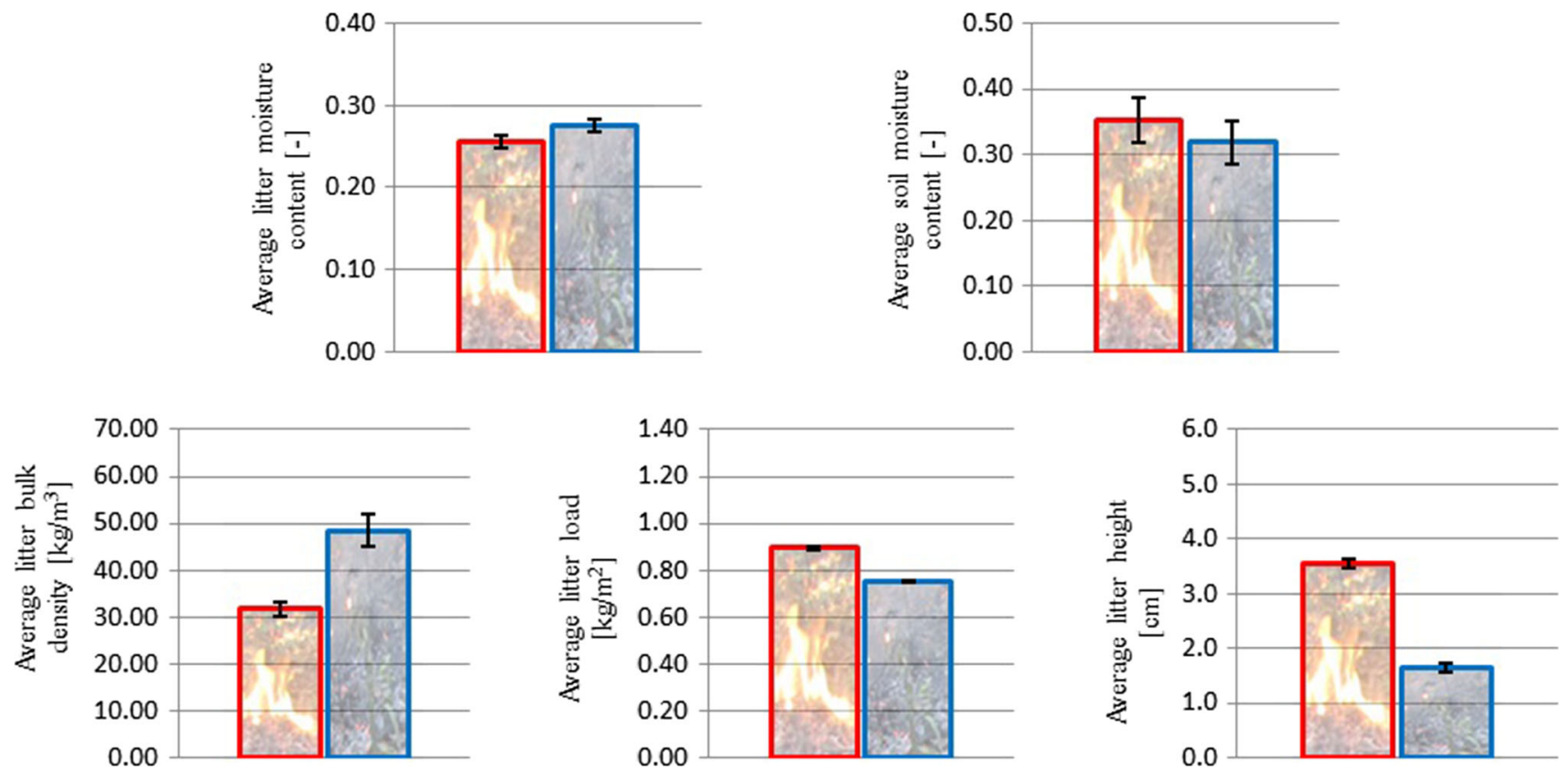

Fig. 4 Graphs show the mean values for the litter moisture content, soil moisture content, litter bulk density, litter load and litter height. The left bar in each graph represents the variable mean value for the

To enable the flammability analysis, the difference between the propagated and self-extinguished values of physical parameters was estimated, along with the uncertainty of the difference and the $t$ test interval estimate of the mean difference. These results are presented in Table 2.

Table 2 shows that the difference of the average values for propagated and self-extinguished fires for litter moisture content, litter bulk density, litter load and litter height is higher than the standard uncertainty of their difference. Conversely, the difference for the average values for propagated and self-extinguished fires for the litter temperature, soil temperature, ambient air temperature, ambient air relative humidity and soil moisture content is fires that propagated up to the site boundaries, while the right bar represents the experiments in which the fire self-extinguished. For each vertical bar, the standard uncertainty is shown in a vertical line

smaller than their combined standard uncertainty. For the variables whose uncertainty of the difference (column 5) is smaller than their difference of the means (column 4), a $t$ test was performed and reported in column 6 . The $t$ test was performed in order to evaluate if propagating and selfextinguishing samples would belong to the same population. If this was the case, there would be no difference between the two samples and they could be considered a single sample. This means that when a variable value can belong to either group (propagating or self-extinguishing fires), it cannot be used to differentiate between the two groups of fires. The uncertainty of the difference and the $t$ test interval estimate of the mean difference are

Table 2 Average values for propagated and self-extinguishing fires and the difference between them

\begin{tabular}{|c|c|c|c|c|c|}
\hline & $\begin{array}{l}\text { Propagating } \\
\text { fires (a) }\end{array}$ & $\begin{array}{l}\text { Self-extinguishing } \\
\text { fires (b) }\end{array}$ & $\begin{array}{l}\text { Difference } \\
\text { (a)-(b) }\end{array}$ & $\begin{array}{l}\text { Uncertainty of } \\
\text { the difference }\end{array}$ & $\begin{array}{l}t \text { Test interval estimate } \\
\text { of the mean difference }\end{array}$ \\
\hline \multicolumn{6}{|l|}{ Measured variables } \\
\hline Litter temperature $\left({ }^{\circ} \mathrm{C}\right)$ & 28.7 & 29.4 & -0.7 & 2.1 & - \\
\hline Litter height $(\mathrm{cm})$ & 3.6 & 1.6 & 1.9 & 0.1 & 0.68 \\
\hline Soil temperature $\left({ }^{\circ} \mathrm{C}\right)$ & 26.3 & 27.1 & -0.9 & 2.1 & - \\
\hline Air temperature $\left({ }^{\circ} \mathrm{C}\right)$ & 31.9 & 32.2 & -0.2 & 0.3 & - \\
\hline Air relative humidity $[-]$ & 61.3 & 61.6 & -0.3 & 2.8 & - \\
\hline \multicolumn{6}{|l|}{ Calculated variables } \\
\hline Litter moisture content $[-]$ & 0.26 & 0.28 & -0.02 & 0.01 & 0.03 \\
\hline Litter bulk density $\left(\mathrm{kg} \mathrm{m}^{-3}\right)$ & 31.64 & 48.43 & -16.79 & 3.83 & 8.59 \\
\hline Litter load $\left(\mathrm{kg} \mathrm{m}^{-2}\right)$ & 0.89 & 0.75 & 0.15 & 0.01 & 0.01 \\
\hline Soil moisture content $[-]$ & 0.35 & 0.30 & 0.05 & 0.05 & - \\
\hline
\end{tabular}



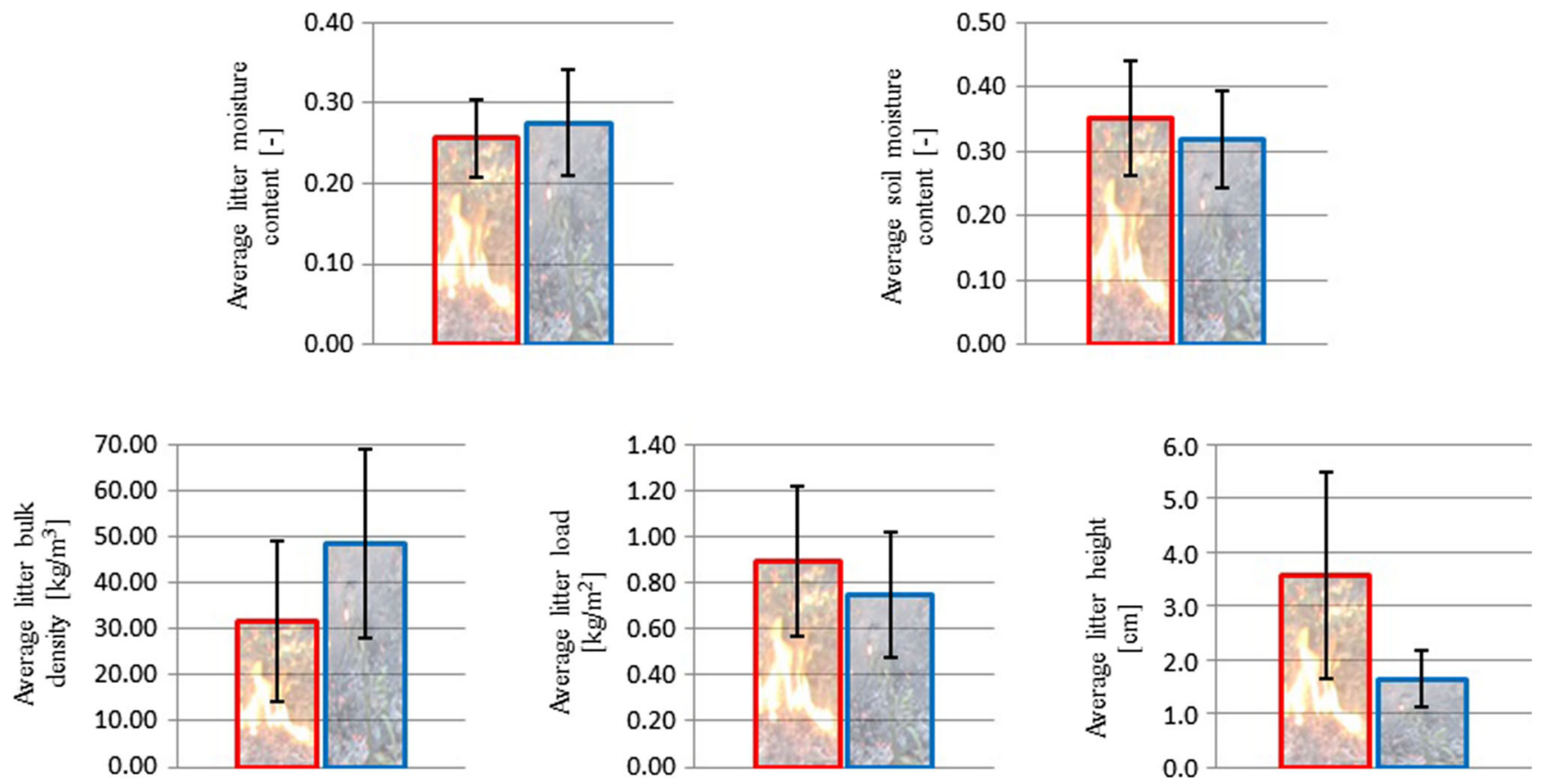

Fig. 5 Graphs show the mean values for the litter moisture content, soil moisture content, litter bulk density, litter load and litter height. The left bar in each graph represents the variable mean value for the

complimentary methods to evaluate if a variable can be used to characterize the propagation or self-extinguishment of a fire. Both methods - uncertainty of the difference and $t$ test-show the same set of statistically representative variables, namely litter moisture content, litter bulk density, litter load and litter height. This analysis is then further used in the logistic regression model that will fit variables data to the probability of fire propagation.

Both the litter and soil moisture content values were expected to have a significant difference between propagated and self-extinguished fires. However, for soil moisture content, the difference in the average values is smaller than the standard uncertainty. This means that, for the fires investigated in this study, the soil moisture content does not play a significant role for the rate of fire propagation, while litter moisture content does.

Figure 5 presents the same data displayed in Fig. 4, except that the standard uncertainty bar was replaced by the standard deviation bar. As observed, litter bulk density, litter load and litter height present a higher coefficient of variation than the litter and soil moisture contents.

Generally speaking, litter surface fire propagation is facilitated when the following combined effects are in place: low litter moisture content, high litter load, high litter height, low litter bulk density, low soil moisture content.

A close look to the data presented in Fig. 5 reveals that the expected trends played their roles in fire propagation. The analysis should consider the averages and the fires that propagated up to the site boundaries, while the right bar represents the experiments in which the fire self-extinguished. For each vertical bar, the standard deviation is shown in a vertical line

respective standard deviations. The expected maximum value for each parameter based on the standard deviation, for the cases in which fire propagated, should be smaller or greater than the cases in which fire self-extinguished, depending on the parameter of interest. For instance, considering that low litter moisture content facilitates fire propagation, Fig. 5 shows that the highest expected value for this parameter (average value plus the standard deviation) is smaller than the highest expected value where fire self-extinguished. The same reasoning, regarding maximum expected values, can be applied to litter bulk density. As suggested, lower litter bulk densities facilitate fire propagation. Considering that litter bulk density is directly related to litter load and litter height, the reasoning is straightforward for these two parameters. As expected, higher litter loads and heights are associated with successful fire propagation.

Regarding the influence of soil moisture in fire propagation, this analysis cannot be performed, seeing that the difference between the average values is smaller than the standard uncertainty for this average difference (see Table 2).

Table 3 presents the correlation among variables, measured or calculated. There are only three correlation coefficients higher than 0.7 , namely the ones between ambient air relative humidity and ambient air temperature (0.98), between soil temperature and litter temperature $(0.87)$ and between litter height and litter bulk density (0.7). The data points collected for ambient air temperature and ambient 
Table 3 Correlation among variables (measured or calculated)

\begin{tabular}{|c|c|c|c|c|c|c|c|c|c|}
\hline & LMC [-] & SMC $[-]$ & $\operatorname{LBD}\left(\mathrm{kg} \mathrm{m}^{-3}\right)$ & $\mathrm{LL}\left(\mathrm{kg} \mathrm{m}^{-2}\right)$ & $\mathrm{LH}(\mathrm{cm})$ & $\mathrm{LT}\left({ }^{\circ} \mathrm{C}\right)$ & ST $\left({ }^{\circ} \mathrm{C}\right)$ & AT $\left({ }^{\circ} \mathrm{C}\right)$ & $\overline{\mathrm{RH}(\%)}$ \\
\hline LMC [-] & 1 & & & & & & & & \\
\hline SMC [-] & $(0.26)$ & 1 & & & & & & & \\
\hline $\operatorname{LBD}\left(\mathrm{kg} \mathrm{m}^{-3}\right)$ & 0.32 & $(0.00)$ & 1 & & & & & & \\
\hline $\operatorname{LL}\left(\mathrm{kg} \mathrm{m}^{-2}\right)$ & 0.11 & 0.09 & 0.41 & 1 & & & & & \\
\hline $\mathrm{LH}(\mathrm{cm})$ & $(0.22)$ & 0.05 & $(0.70)$ & 0.21 & 1 & & & & \\
\hline $\operatorname{LT}\left({ }^{\circ} \mathrm{C}\right)$ & 0.09 & 0.39 & 0.27 & 0.24 & 0.08 & 1 & & & \\
\hline $\mathrm{ST}\left({ }^{\circ} \mathrm{C}\right)$ & 0.19 & 0.24 & 0.26 & 0.27 & 0.16 & 0.87 & 1 & & \\
\hline $\mathrm{AT}\left({ }^{\circ} \mathrm{C}\right)$ & 0.33 & $(0.31)$ & 0.04 & 0.13 & $(0.05)$ & $(0.05)$ & $(0.11)$ & 1 & \\
\hline $\mathrm{RH}(\%)$ & $(0.25)$ & 0.34 & 0.03 & $(0.14)$ & 0.02 & 0.19 & 0.25 & $(0.98)$ & 1 \\
\hline
\end{tabular}

LMC litter moisture content, $S M C$ soil moisture content, $L B D$ litter bulk density, $L L$ litter load, $L H$ litter height, $L T$ litter temperature, $S T$ soil temperature, $A T$ ambient air temperature, $R H$ ambient air relative humidity

air relative humidity represent a 24-h recording from August 20, 2014, to August 24, 2014. Data recorded on August 25, 2014, ended at 18:00 h. Although in this experimental investigation meteorological parameters did not influence the surface fire flammability, they are useful in physical numerical models. For the period of investigation, no correlation was observed between ambient air relative humidity and litter moisture content. The same conclusion applies to soil and litter moisture contents, despite the fact that litter biomass interacts, to some extent, with the ambient air and the soil. In addition, ambient air temperature and litter temperature data do not show a correlation between these two parameters. The correlation between soil and litter temperature is to some extent expected, because of the physical proximity of the two layers. The correlation between litter height and litter bulk density will always appear, since the litter bulk density is calculated taking the litter height into consideration.

\section{Logistic regression model}

After the vegetation ignition is successful, what follows is either fire propagation or self-extinguishment. This binary result is influenced by vegetation, soil and weather properties. The mathematical model that treats continuous input variables and provides a binary outcome is the logistic regression model (Montgomery and Runger 2014).
In general, all logistic regression models have the same propagation/extinction probability equation (Eq. 2). What changes are the independent variables $(\Theta)$ and their corresponding coefficients $(\beta)$ in the logistic equation (Eq. 1). Equation (1) is also known as the index of the logistic regression model. Wilson (1985) and Dickinson et al. (2013) present their index in a form that is not a polynomial shape, but the fire propagation probability is the same as in Eq. (2).

$\beta \Theta=\beta_{0}+\beta_{1} * \Theta_{1}+\beta_{2} * \Theta_{2}+\cdots+\beta_{n} * \Theta_{n}$

$\operatorname{Pr}($ spread $=Y)=\frac{e^{\beta \Theta}}{1+e^{\beta \Theta}}$

Fire propagation occurs when $\operatorname{Pr}>0.5$, while extinction occurs otherwise.

The data presented in this study were used as input to existing logistic models (Wilson 1985; Weise et al. 2005; Zhou et al. 2005; Fernandes et al. 2008; Dickinson et al. 2013) applied to propagation/extinction outcomes. Although the litter vegetation found in the Brazilian rainforest differs from the vegetation types presented in these past studies, an assessment was performed to check how well each one would predict the litter flammability observed in our field experiments. Table 4 summarizes the results. True positive rate identifies the percentage of positives that are correctly identified as such. True negative rate identifies the percentage of negatives that are correctly
Table 4 Logistic regression models results

\begin{tabular}{lllccl}
\hline & Wilson (\%) & Weise (\%) & Zhou (\%) & Fernandes $(\%)$ & Dickinson (\%) \\
\hline True positive rate & 51 & 54 & 100 & 100 & 83 \\
True negative rate & 73 & 68 & 3 & 3 & 65 \\
Average & 62 & 61 & 52 & 52 & 74 \\
\hline
\end{tabular}

True positive rate identifies the percentage of positives that are correctly identified as such. True negative rate identifies the percentage of negatives that are correctly identified as such. Correctly identifying true negatives is very important, as no one would like to predict a fire to not propagate and in fact it propagates 
identified as such. Correctly identifying true negatives is very important, as no one would like to predict a fire to not propagate and in fact it propagates.

Data from the field experiments presented in this paper when used as input data to the models of Weise et al. (2005) and Zhou et al. (2005) were not expected to be good, since these two models consider wind speed and terrain slope in the logistic equation, which are both zero for this study of the Brazilian rainforest litter. One reason for Weise et al. (2005) to perform better than Zhou et al. (2005) is that the logistic equation coefficients in the former model for wind speed and terrain slope are smaller and vegetation moisture content is higher than the coefficients in the latter.

Fernandes et al. (2008) presented four different indexes for their logistic regression model. Using our experimental data in these indexes and models showed the same true positive rate and true negative rate for all four models. The reason is the choice of the index parameters, which are not as significant for this study as it was for theirs.

Wilson (1985) and Dickinson et al. (2013) have basically the same formulation for the indexes, which are not polynomials. Wilson (1985) calibrated his model for porous beds of woody fuels and Dickinson et al. (2013) for mixed wood boreal forest surface fuels. Because Dickinson et al. (2013) fuels are more similar to our fuels, their model provided better results with our experimental data. Nonetheless, none of the models considered performed very well using our data from the Brazilian rainforest. For this reason, we developed a logistic regression model based on variables important for describing rainforest surface fires.

In order to evaluate the independent variables appropriate to the logistic regression model for our dataset, a bivariate correlation was run using the following input parameters: litter moisture content (LMC), soil moisture content (SMC), litter bulk density (LBD), litter load (LL), litter height (LH), litter temperature (LT), soil temperature (ST), ambient air temperature (AT) and ambient air relative humidity (RH). The strongest correlations were between the ambient air temperature and the ambient air relative humidity $(-0.92)$ and between litter temperature and soil temperature (0.82). The strong correlation between air temperature and air relative humidity is already shown in Table 3 . Thus, the list of independent variables for the logistic regression model equation had the ambient air relative humidity removed. For the same reason, the soil temperature was removed from the list. Considering that the litter bulk density is the division of the litter load by the litter height, choosing the litter bulk density as an independent variable would exclude the litter load and the litter height. On the other hand, picking either litter load or litter height, or both, would exclude the choice of the litter bulk density as an independent variable. The choice was to remove the litter bulk density from the list of variables for the logistic regression model equation. At this point, a logistic regression analysis was run with the remaining variables: litter moisture content, soil moisture content, litter load, litter height, litter temperature and ambient air temperature. This is referred to as the saturated model. In order to obtain a reduced model, a sensitivity analysis was conducted excluding one variable at a time. This showed that litter moisture content and litter height are the only independent variables that are statistically significant under a significance level of 0.05. It is important to note that litter moisture content and litter height were also classified as statistically significant by the methods of the uncertainty of the difference and $t$ test (Table 2).

The general polynomial equation presented in Eq. (1) is then rewritten as

$\beta \Theta=-0.16 * \mathrm{LMC}+0.19 * \mathrm{LH}$

The results from the logistic equation provided sensitivity (true positive rate) of $71 \%$ and specificity (true negative rate) of $84 \%$, and an average value of $78 \%$. Results from this logistic regression model are better than the ones presented in Table 4.

Table 5 presents the statistical data and the polynomial coefficients for the litter moisture content and the litter height. In the table, SE stands for standard error, and Wald is the Wald test used to test a single or multiple hypothesis on single or multiple parameters. Significance means the significance level for the Wald test. If the significance is smaller than or equal to the $P$ value, the variable is considered statistically significant. In this study, a $P$ value of 0.05 was considered, which corresponds to the probability of observing such an extreme value by chance.

Fit between Eq. (3) and spread behavior in Brazilian rainforest litter is illustrated in Fig. 6.

\section{Summary and conclusions}

Fire experiments in the Brazilian rainforest litter were carried out in the State of Rondônia. The field conditions for a surface fire spreading through a litter bed were recorded in 72 experiments, in which $49 \%$ of the fires propagated. Based on the statistical analysis, a logistic regression model for fire propagation was proposed and its coefficients were fitted to the experimental results. The relevant parameters for fire propagation were litter height and litter moisture content. The logistic regression model

Table 5 Parameters of the extinction index estimated from logistic regression for the Brazilian rainforest litter

\begin{tabular}{lcccl}
\hline Variable & Variable coefficient & SE & Wald & Significance \\
\hline LMC & -0.16 & 0.04 & 14.92 & 0.000 \\
LH & 0.19 & 0.05 & 13.10 & 0.000 \\
\hline
\end{tabular}


Fig. 6 Spread/no spread prediction in Brazilian rainforest litter using the logistic model developed from 72 burns. Experimental values (square symbols) and predicted values (diamond symbols) for the model are shown

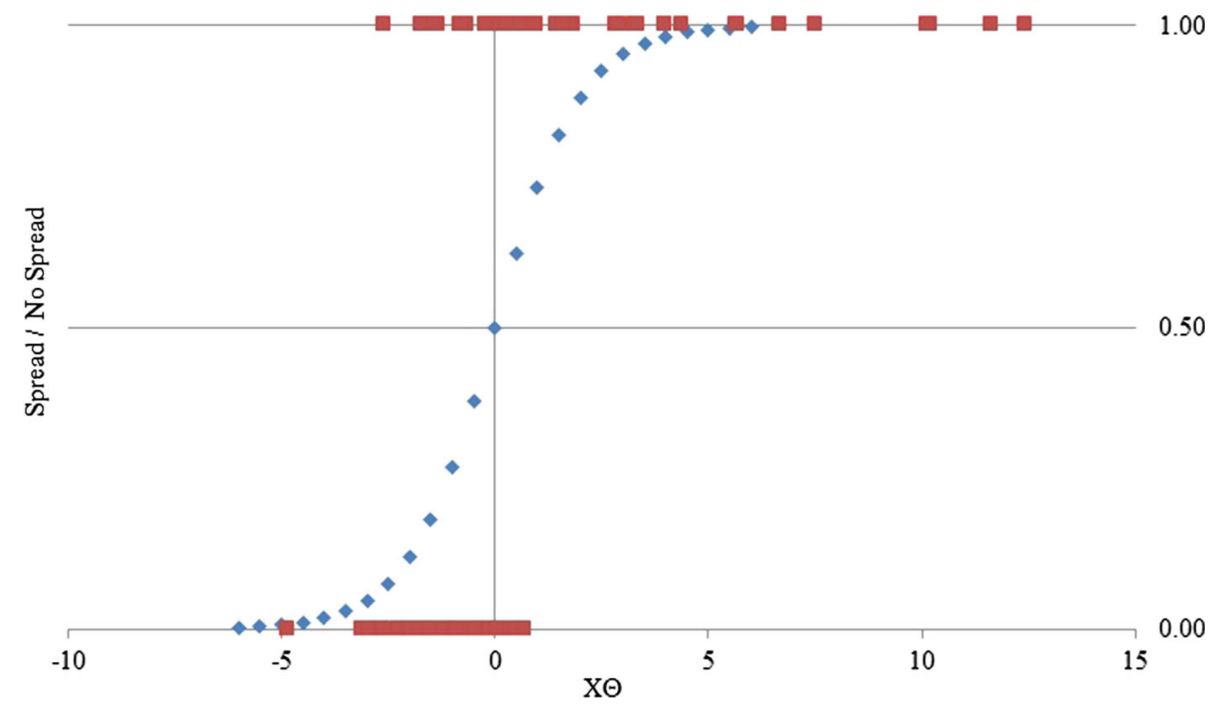

provided very good results, as sensitivity (true positive rate) is $71 \%$ and specificity (true negative rate) is $84 \%$, with an average value of $78 \%$. This logistic regression model can be easily applied to management of surface fires. With the input of only two parameters, litter height and litter moisture content, which are easily obtained, one evaluates the probability of fire propagation. This information is important for evaluating forest fires risk.

Surface fire, as natural phenomena, has intrinsic high variability, as shown in the analyses. With this high variability and with the data measured in the field, a statistically representative correlation between ROS and the physical parameters was not obtained. Nevertheless, a set of average values, standard deviations, coefficient of variation and standard uncertainties of the physical parameters for propagating and self-extinguished fire were reported. The averaged calculated ROS is $15.1 \pm 1.2 \mathrm{~cm} \mathrm{~min}^{-1}$. This experimental study also provides a comprehensive set of physical parameters that are important for numerical simulations of surface fire propagation in the Brazilian rainforest.

Acknowledgements Partial funding for this work was received from the São Paulo Research Foundation (FAPESP) Programs under Project 2008/04490-4 and 2011/20679-2, which is gratefully acknowledged.

\section{Appendix 1}

This appendix presents the equations necessary for understanding the statistical approach used herein.

An estimate for the litter bulk density of the dry vegetation was obtained from the measured litter dry mass and an estimated volume of the litter, which gives
$\mathrm{LBD}=\frac{m_{\mathrm{dry}}}{V_{\text {litter }}}$

The litter moisture content is represented by the following equation

$\mathrm{LMC}=\frac{\left(m_{\mathrm{wet}}-m_{\mathrm{dry}}\right)}{m_{\mathrm{dry}}}$

The litter load is

$\mathrm{LL}=\frac{\left(m_{\mathrm{wet}}-m_{\mathrm{dry}}\right)}{A_{\text {litter }}}$

The litter residue fraction is given by

$\mathrm{LRF}=\frac{m_{\text {residue }}}{m_{\text {dry }}}$

The soil moisture content is represented by the following equation

$\mathrm{SMC}=\frac{\left(m_{\text {soil wet }}-m_{\text {soil dry }}\right)}{m_{\text {soil dry }}}$

The ROS is given by

$\operatorname{ROS}=\frac{\Delta d}{\Delta t}$

where $\Delta d$ is the distance between two thermocouples and $\Delta t$ is the time for the fire to travel between the two thermocouples.

The statistical parameters are represented by the formulas below. The average is the sum of a list of numbers divided by the number of numbers in the list:

$\bar{x}=\frac{1}{n} \sum_{i=1}^{n} x_{i}$

and the standard deviation, which is a measure used to quantify the amount of variation or dispersion of a set of data values, is represented by 
Table 6 Measurands, devices and models, Type B standard uncertainties and sources of uncertainty

\begin{tabular}{|c|c|c|c|c|}
\hline Measurand & Sensor/device & Model & $\begin{array}{l}\text { Type B standard } \\
\text { uncertainty }\end{array}$ & $\begin{array}{l}\text { Source of } \\
\text { uncertainty }\end{array}$ \\
\hline Litter mass $(\mathrm{g})$ & Spring scale & Pesola, Micro-Line & 0.20 & Calibration error \\
\hline Dry litter mass (DLM) (g) & Spring scale & Pesola, Micro-Line & 0.29 & Calibration error \\
\hline Soil mass $(\mathrm{g})$ & Spring scale & Pesola, Medio-Line & 2.04 & Calibration error \\
\hline Soil mass $(\mathrm{g})$ & Spring scale & Pesola, Medio-Line & 2.89 & Calibration Error \\
\hline Litter height $(\mathrm{LH})(\mathrm{cm})$ & Rule & & 0.001 & Calibration error \\
\hline Litter temperature (LT) $\left({ }^{\circ} \mathrm{C}\right)$ & Infrared thermometer & RayTek MiniTemp MT6 & 1.5 & Calibration error \\
\hline Soil temperature $(\mathrm{ST})\left({ }^{\circ} \mathrm{C}\right)$ & Infrared thermometer & RayTek MiniTemp MT6 & 1.5 & Calibration error \\
\hline Air Temperature (AT) $\left({ }^{\circ} \mathrm{C}\right)$ & NTC & LUFFT-WS601-UMB & 0.2 & Calibration error \\
\hline Air relative humidity $(\mathrm{RH})(\%)$ & Capacitive & LUFFT-WS601-UMB & 2 & Calibration error \\
\hline Wind speed $(\mathrm{m} / \mathrm{s})$ & Cup anemometer & Lutron AM-4201 & $2 \%+1 d$ & Calibration error \\
\hline Wind speed $(\mathrm{m} / \mathrm{s})$ & Ultrasonic-meteorological station & Lufft-WS601-UMB & 0.3 & Calibration error \\
\hline Wind direction (degrees) & Ultrasonic-meteorological station & Lufft-WS601-UMB & 3 & Calibration error \\
\hline Fire travelled distance $(\mathrm{cm})$ & Rule & & 10 & $\begin{array}{l}\text { Positioning of the } \\
\text { thermocouples }\end{array}$ \\
\hline Fire elapsed time (s) & Thermocouples K-type/datalogger & & 0.3 & $\begin{array}{l}\text { Calibration error } \\
\text { correction error }\end{array}$ \\
\hline
\end{tabular}

$\sigma=\sqrt{\frac{1}{n-1} \sum_{i=1}^{n}\left(x_{i}-\bar{x}\right)^{2}}$

The combined standard uncertainty is needed for the calculated quantities, and its form depends on the mathematical relationship involving the measured quantities. The equations below represent the standard combined uncertainty, $u_{\mathrm{c}}$, for the litter bulk density, litter moisture content, litter load, litter residue fraction, soil moisture content and ROS, respectively. All the uncertainties were estimated using the Type B method. Table 6 presents the data necessary for computing the combined standard uncertainties of the measurand using the following equations (note that values of $u_{\mathrm{c}}$ are reported in Table 2; also please refer to "List of symbols" for the meaning of the variables below).

$u_{\mathrm{cLBD}}=\sqrt{\left(\frac{1}{\mathrm{~A} \mathrm{LH}}\right)^{2} u_{\mathrm{DLM}}^{2}+\left(-\frac{\mathrm{DLM}}{A(\mathrm{LH})^{2}}\right)^{2} u_{\mathrm{DLM}}^{2}}$

$u_{\mathrm{cLMC}}=\sqrt{\left(\frac{1}{\mathrm{DLM}}\right)^{2} u_{\Delta \mathrm{LM}}^{2}+\left(-\frac{\Delta \mathrm{LM}}{(\mathrm{DLM})^{2}}\right)^{2} u_{\mathrm{DLM}}^{2}}$

$u_{\mathrm{cLL}}=\sqrt{\left(\frac{1}{A}\right)^{2} u_{\mathrm{DLM}}^{2}+\left(-\frac{\mathrm{DLM}}{(A)^{2}}\right)^{2} u_{\mathrm{A}_{\mathrm{litter}}}^{2}}$
$u_{\mathrm{cLRF}}=\sqrt{\left(\frac{1}{\mathrm{DLM}}\right)^{2} u_{m_{\text {residue }}}^{2}+\left(-\frac{m_{\text {residue }}}{(\mathrm{DLM})^{2}}\right)^{2} u_{\mathrm{DLM}}^{2}}$

$u_{\mathrm{cSMC}}=\sqrt{\left(\frac{1}{\mathrm{DSM}}\right)^{2} u_{\Delta \mathrm{SM}}^{2}+\left(-\frac{\Delta \mathrm{SM}}{(\mathrm{DSM})^{2}}\right)^{2} u_{\mathrm{DSM}}^{2}}$

$u_{\mathrm{cROS}}=\sqrt{\left(\frac{1}{\Delta t}\right)^{2} u_{\Delta d}^{2}+\left(\frac{\Delta d}{(\Delta t)^{2}}\right)^{2} u_{\Delta t}^{2}}$

where $\Delta \mathrm{t}$ represents the elapsed time measured between two thermocouples and $\Delta \mathrm{d}$ the distance travelled by the fire front.

The uncertainty of measurands difference, as presented in Table 2, is calculated by

$u_{\mathrm{c}}=\sqrt{\left(u_{\text {propagated }}\right)^{2}+\left(u_{\text {self-extinguished }}\right)^{2}}$

Table 6 presents the estimation of the Type B standard uncertainties of the measurands.

\section{Appendix 2}

See Tables 7 and 8 . 


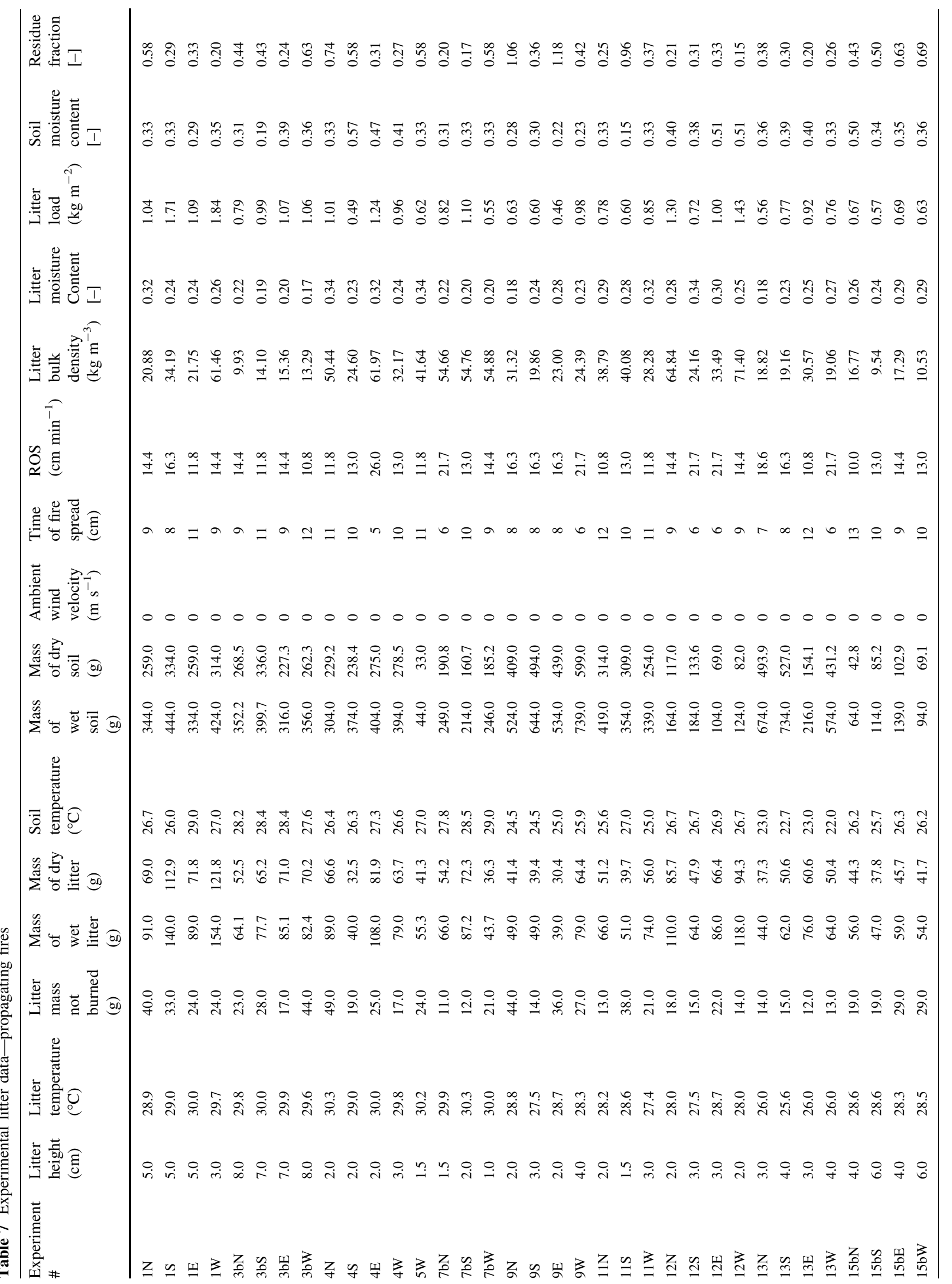




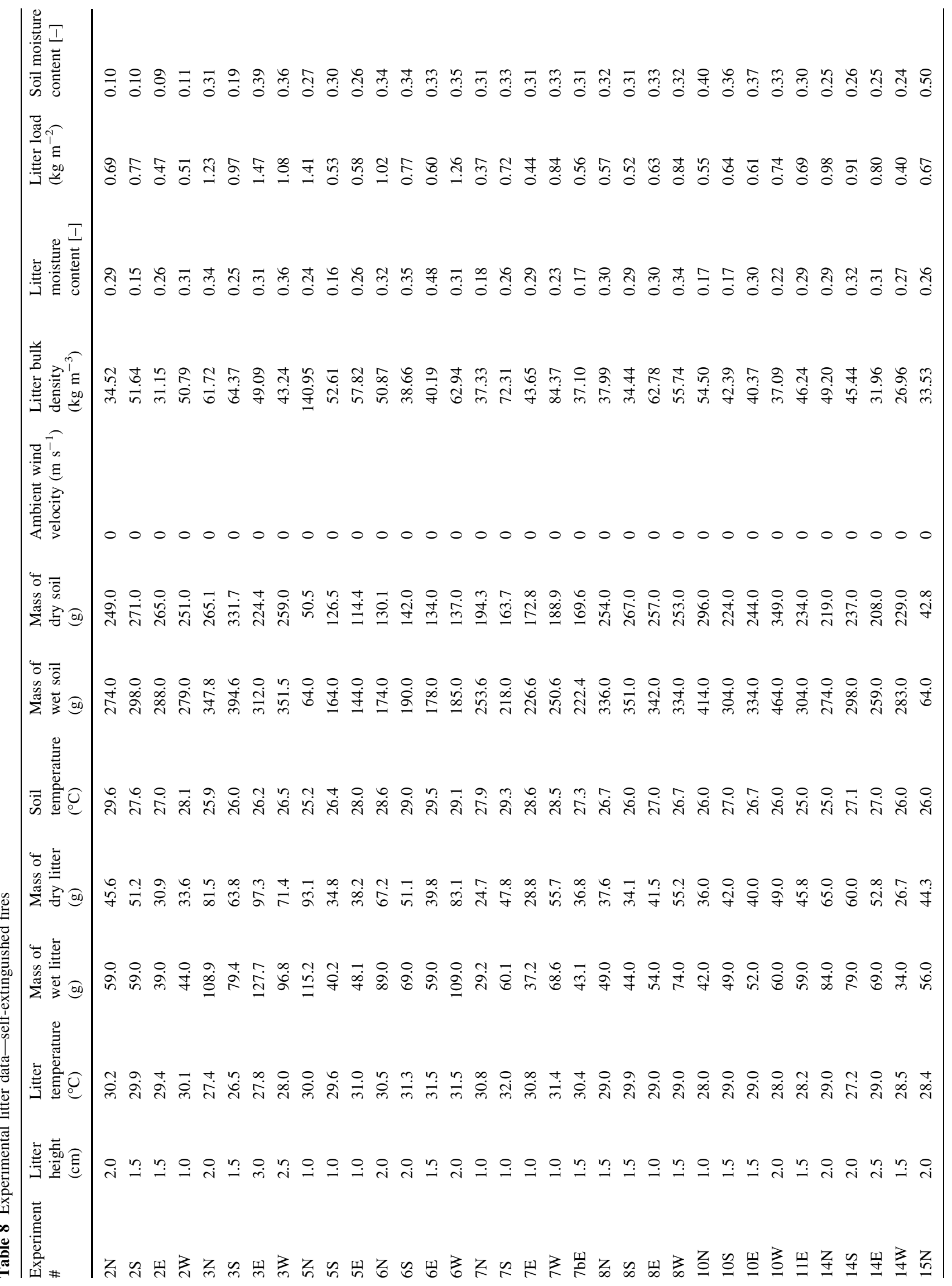




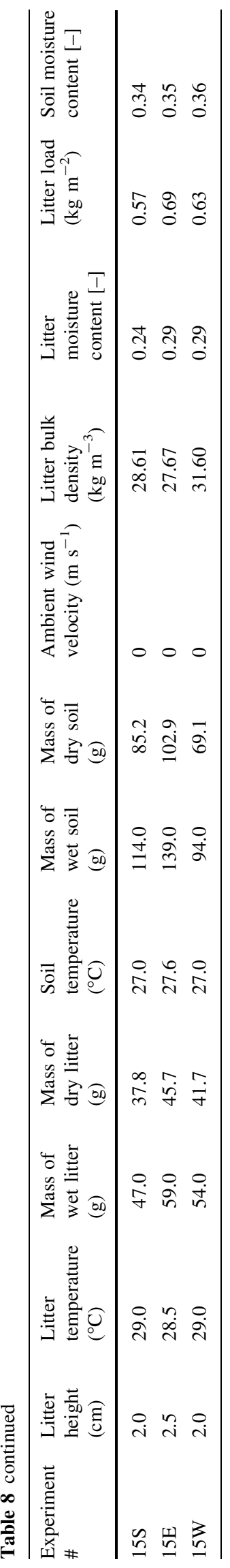

\section{References}

Alencar A, Brando PM, Asner GP, Putz FE (2015) Landscape fragmentation, severe drought, and the new Amazon forest fire regime. Ecol Appl 25:1493-1505

Araújo TM, Carvalho JA Jr, Higuchi N, Brasil ACP Jr, Mesquita ALA (1999) A tropical rainforest clearing experiment by biomass burning in the state of Pará, Brazil. Atmos Environ 33:1991-1998

Balch JK, Brando PM, Nepstad DC, Coe MT, Silvério D, Massad TJ, Davidson EA, Lefebvre P, Oliveira-Santos C, Rocha W, Cury RTS, Parsons A, Carvalho KS (2015) The susceptibility of southeastern Amazon forests to fire: insights from a large-scale burn experiment. Bioscience 65(9):893-905

Bufacchi P (2014) Simulação numérica de incêndios de superfície na região amazônica com modelo de turbulência de grandes estruturas. Ph.D. Thesis, University of São Paulo, São Paulo, Brazil

Bufacchi P, Krieger GC, Mell W, Alvarado E, Santos JC, Carvalho JA Jr (2016) Numerical simulation of surface forest fire in Brazilian Amazon. Fire Saf J 79:44-56. doi:10.1016/j.firesaf. 2015.11.014

Carvalho JRJA, Santos JM, Santos JC, Leitão MM (1995) A tropical rainforest clearing experiment by biomass burning in the Manaus region. Atmos Environ 29:2301-2309

Carvalho JA Jr, Costa FS, Gurgel Veras CA, Sandberg DV, Alvarado EC, Gielow R, Serra AMJR, Santos JC (2001) Biomass fire consumption and carbon release rates of rainforest-clearing experiments conducted in northern Mato Grosso, Brazil. J Geophys Res 106(D16):17877-17888

Carvalho ER, Veras CAG, Carvalho JRJA (2002) Experimental investigation of smouldering in biomass. Biomass Bioenergy 22:283-294

Carvalho JA Jr, Veras CAG, Alvarado EC, Sandberg DV, Gielow R, Carvalho ER, Santos JC (2010) Understory fire propagation and tree mortality on adjacent areas to an Amazonian deforestation fire. Int J Wildland Fire 19:795-799

Clements CB, Zhong S, Goodrick S, Li J, Potter BE, Bian X, Heilman WE, Charney JJ, Perna R, Jang M, Lee D, Patel M, Street S, Aumann G (2007) Observing the dynamics of wildland grass fires: FireFlux - a field validation experiment. Bull Am Meteorol Soc 88:1369-1382

Cochrane MA, Laurance WF (2008) Synergisms among fire, land use, and climate change in the Amazon. Ambio 37:522-527

Cochrane M, Alencar A, Schulze M, Souza C, Nepstad DC, Lefebvre P, Davidson E (1999) Positive feedbacks in the fire dynamic of closed canopy tropical forest. Science 284:1837-1841

Dickinson MB, Johnson EA, Artiaga R (2013) Fire spread probabilities for experimental beds composed of mixedwood boreal forest fuels. Can J For Res 43:321-330

Dimitrakopoulos AP, Papaioannou KK (2001) Flammability assessment of Mediterranean forest fuels. Fire Technol 37:143-152

Fernandes PM, Botelho H, Rego F, Loureiro C (2008) Using fuel and weather variables to predict the sustainability of surface fire spread in maritime pine stands. Can J For Res 38:1-19

INPE (2015) http://sigma.cptec.inpe.br/queimadas. Accessed 05 March 2015

Malhi Y, Roberts T, Betts RA, Killeen TJ, Li W, Nobre CA (2008) Climate change, deforestation, and the fate of the Amazon. Science 319:169-172

Mell WE, Jenkins MA, Gould J, Cheney P (2007) A physics based approach to modeling grassland fires. Int $\mathrm{J}$ Wildland Fire $16: 1-22$

Mell WE, Maranghides A, McDermott R, Manzello S (2009) Numerical simulation and experiments of burning Douglas fir trees. Combust Flame 156:2023-2041 
Montgomery DC, Runger GC (2014) Applied statistics and probability for engineers. Wiley, Hoboken

Morandini F, Silvani X, Rossi L, Santoni PA, Simeoni A, Balbi JH, Rossi JL, Marcelli T (2006) Fire spread experiment across Mediterranean shrub-influence of wind on flame front properties. Fire Saf J 41:229-235

Morvan D, Dupuy JL (2001) Modeling fire spread through a forest fuel bed using a multiphase formulation. Combust Flame 127:1981-1984

Morvan D, Dupuy JL (2004) Modeling the propagation of a wildfire through a Mediterranean shrub using a multiphase formulation. Combust Flame 138:199-210

National Institute of Standards and Technology (2016) http://physics. nist.gov/cuu/Uncertainty/basic.html. Accessed 01 April 2016

Santoni PA, Simeoni A, Rossi JL, Bosseur F, Morandini F, Silvani X, Balbi JH, Cancellieri D, Rossi L (2006) Instrumentation of wildland fire-characterisation of a fire spreading through a Mediterranean shrub. Fire Saf J 41:171-184
Silva RG (1998) Manual de prevenção e combate aos incêndios florestais. Brasília: Instituto Brasileiro do Meio Ambiente e dos Recursos Naturais Renováveis

Silvani X, Morandini F (2009) Fire spread experiments in the fieldtemperature and heat fluxes measurements. Fire Saf J 44:279-285

Weise DR, Zhou X, Sun L, Mahalingham S (2005) Fire spread in chaparral-'go or no-go?' Int. J Wildland Fire 14:99-106

Wilson RA Jr (1985) Observations of extinction and marginal burning states in free burning porous fuel beds. Combust Sci Technol 44:179-193. doi:10.1080/00102208508960302

WWF-Brasil (2015) http://www.wwf.org.br/. Accessed 05 Sep 2015

Zhou X, Weise D, Mahalingam S (2005) Experimental measurements and numerical modeling of marginal burning in live chaparral fuel beds. Proc Combust Inst 30:2287-2294 